\title{
Impact of Plant Growth Promoting Rhizobacteria with FYM on the Growth, Yield Attribute and Yield of Tomato (Lycopersicon esculentum Mill.)
}

\author{
Gagendra Singh Rajput* and P.W. Ramteke \\ Department of Biological Sciences, Sam Higginbottom Institute of Agriculture, Technology \& \\ Sciences (Deemed-to be University), Allahabad-211007, India
}

*Corresponding author

\begin{tabular}{|c|}
\hline Keywords \\
\hline $\begin{array}{l}\text { Tomato, PGPR, } \\
\text { FYM and N.P.K. }\end{array}$ \\
\hline Article Info \\
\hline $\begin{array}{l}\text { Accepted: } \\
\text { 22 August } 2019 \\
\text { Available Online: } \\
\text { 10 September } 2019\end{array}$ \\
\hline
\end{tabular}

A B S T R A C T

PGPB are free-living soil, rhizosphere, rhizoplane, and phylosphere bacteria that, under some conditions, are beneficial for plants Most of the activities of PGPB have been studied in the rhizosphere. PGPB promote plant growth by directly affect the metabolism of the plants by providing substances that are usually in short supply. The present investigation was conducted at Department of Biological Sciences, Sam Higginbottom Institute of Agriculture, Technology and Sciences (Deemed-to-be University) Allahabad, during Rabi season 2015-16. Tomato plants variety NTL-186 was transplanted in pot during $2^{\text {nd }}$ week of Fabuary. The experiment was carried out using 11 treatments with three replication on completely randomized design. There are five different PGPR are selected namely (PR3, PR5, PR6, PR24 and PR29) along with FYM 10 t/ha and Fertilizer dose (NPK) 120:60:50 NPK- kg/ha. Results revealed that PGPR strain PR6 along with $\mathrm{T}_{7}[\mathrm{NPK}(100 \%)$ and FYM(100\%)] showed the highest seed germination (100\%), root length of seedling (6.00 $\mathrm{cm})$, shoot length of seedling $(6.43 \mathrm{~cm})$, plant height 60 DAT $(70.10 \mathrm{~cm})$,number of branches per plant 60 DAT (14.67), number of leaves/plants 60 DAT (50.33), total number of flowers/ plant (20.33), fresh weight of plant (42.28g/plant) and dry weight of plant $(14.16 \mathrm{~g} / \mathrm{plant})$ obtained all the data were statistically significant. From the present investigation it concluded that $\mathrm{T}_{7}(\mathrm{PR} 6+\mathrm{NPK}(100 \%)+\mathrm{FYM}(100) \%)$ significantly increased the growth and yield of Tomato (Lycopersicon esculentum Mill.).

\section{Introduction}

Tomato (Lycopersicon esculentum Mill.) belongs to family solanaceae having chromosome number $(2 \mathrm{n}=24)$. Officially the cultivated tomato belongs to the order Scrophulariales, suborder Solanineae, family Solanaceae, tribe Solaneae, genus
Lycopersicon, subgenus Eulycopersicon, species Lycopersicon esculentum (lycopersicon $=$ wolf peach, esculentum $=$ edible). It is a self pollinated crop and PeruEquador region is considered to be the centre of origin. it can also be identified as Solanum lycopersicon, as originally classified by Linnaeus in 1753 , because of the similarity 
between tomatoes and potatoes. Tomato was introduced by the Portuguese. This fruit contains a variety of micro components, such as lycopene (an antioxidant), potassium, vitamins (A, C, E and $\mathrm{K}$ ), sucrose and folic acid (Peralta and spooner, 2007). The tomato (Lycopersicum esculentum Mill.) is an important vegetable crop worldwide. Tomato being an important vegetable crop and photoperiod insensitive and can be cultivated throughout the year. Its cultivation has spread throughout the world occupying an area of $3.5 \times 10^{6}$ ha with the production of $1 \times 10^{6}$ tons (FAO, 2010). In India, it occupies an area of 0.54 million ha with a production of 7.60 million tons with an average yield of 14.074 tons $\mathrm{ha}^{-1}$ (Anonymous, 2006). (Ramakrishnan and Selvakumar, 2012). Tomatoes contribute to a healthy, well-balanced diet. They are rich in minerals, vitamins, essential amino acids, sugars and dietary fibres. Tomato contains much vitamin $\mathrm{B}$ and $\mathrm{C}$, iron and phosphorus. Tomato fruits are consumed fresh in salads or cooked in sauces, soup and meat or fish dishes. They can be processed into purées, juices and ketchup. Canned and dried tomatoes are economically important processed products. Yellow tomatoes have higher vitamin A content than red tomatoes, but red tomatoes contain lycopene, an antioxidant that may contribute to protection against carcinogenic substances. (Naika et al., 2005).

Plant growth-promoting bacteria (PGPB) are defined as free-living soil, rhizosphere, rhizoplane, and phylosphere bacteria that, under some conditions, are beneficial for plants Most of the activities of PGPB have been studied in the rhizosphere, and to lesser extent on the leaf surface; endophytic PGPB that reside inside the plant have also been found. PGPB promote plant growth in two different ways: (1) They directly affect the metabolism of the plants by providing substances that are usually in short supply.
These bacteria are capable of fixing atmospheric nitrogen, of solubilizing phosphorus and iron, and of producing plant hormones, such as auxins, gibberellins, cytokinins, and ethylene. Additionally, they improve a plant's tolerance to stresses, such as drought, high salinity, metal toxicity, and pesticide load. One or more of these mechanisms may contribute to the increases obtained in plant growth and development that are higher than normal for plants grown under standard cultivation conditions. However, these bacteria do not enhance the genetic capacity of the plant, as genetic material is not transferred. (2) A second group of PGPB, referred to as biocontrol-PGPB, indirectly promote plant growth by preventing the deleterious effects of phytopathogenic microorganisms (bacteria, fungi, and viruses). They produce substances that harm or inhibit other microbes, but not plants. (Hillel., 2005).

It is well known that rhizosphere and soil microorganisms (PGPR) play an important role in maintaining crop and soil health through versatile mechanisms: nutrient cycling and uptake, suppression of plant pathogens, induction of resistance in plant host, direct stimulation of plant growth (Kloepper and Schroth 1981) Plant Growth Promoting Rhizobacteria (PGPR), especially Pseudomonas fluorescens (Pf1, Py15 and Fp7) strains have been developed commercially as a talc based formulation and tested against several crop diseases (Kavino et al.,2007) Several approaches have been tried for the sustainable management of early blight in tomato.

However, no attempts have been made for the management of early blight disease with PGPR strains. Therefore, the present study was designed to evaluate protective effect of PGPR strains (Pseudomonas spp.) against tomato early blight disease caused by $A$. solani. (Maurya et al., 2015). 
Organic manuring is becoming an important component of environmentally sound Sustainable agriculture. Residual nature of organic sources makes them more value based for the whole system compared to individual crops. Organic materials hold great promise as a source of multiple nutrients and ability to improve soil characteristics. Recently, the use of organic materials as fertilizers for crop production has received attention for sustainable crop productivity. In organic production system, organic wastes and other biological materials, as available in situ are utilized along with beneficial microbes to release the nutrients to crops. (Jenny and Malliga, 2016). Farm Yard Manure (FYM) is the manure produced in the farm which is made up of excreta (dung and urine) of farm animals, the bedding materials provided for them and miscellaneous farm and house hold wastes. The bedding material is called ,litter and it absorbs urine voided by animals. It is not a standardized product and its value depends on the kind of feed fed to the animal, the amount of straw used and the manner of storage. FAO defined organic agriculture as a unique production management system which promotes and enhances agro-ecosystem health, including biodiversity, biological cycle and soil biological activity, and this is accomplished by using on-farm agronomic, biological and mechanical methods in exclusion of all synthetic off-farm inputs.

However making available all the essential nutrients for plant growth and maintaining a living soil to achieve sustainable yield is challenging task. Organic agriculture in short term, produces lower crop yields but in the long-term it may produce higher yields. (Chatterjee and Thirumdasu, 2014). Keeping all this point in mind present investigation were made to see effect of PGPR (PR3, PR5, PR6, PR24 and PR29) and FYM on growth and yield parameter of Tomato (Lycopersicon esculentum Mill.).

\section{Materials and Methods}

\section{Site descriptions}

The pot experiment was conducted during year 2015-16 at in the month of January to April in Department of Biological Sciences, Allahabad School of Agriculture SHIATS, Allahabad. Allahabad is situated in the agroclimatic zone (Sub-tropical belt) of Uttar Pradesh. The Geographical area falls under sub-tropical climate and is located in between 25.870 North latitude and 81.250 E longitudes at an altitude of 98 meter above the mean sea level (MSL). The area of Allahabad district comes under sub tropical belt in the south eastern Uttar Pradesh, which experience extremely hot summer and fairly cold winter. The maximum temperature of the location reaches up to $460 \mathrm{C}$ to $480 \mathrm{C}$ and seldom falls as low as $40 \mathrm{C}$ to $50 \mathrm{C}$. The Relative humidity ranged between 20 to $94 \%$. The average rainfall in this area is around 850-1100 mm annually.

\section{Experiment and treatment details}

Soil is collected from the surface $(0-15 \mathrm{~cm})$ in the field, (unless you are looking at sub-soil properties). The soil is then sieved through a screen or plastic sieve with a mesh of approximately $5 \mathrm{~mm}$ openings to remove rocks, clods and large pieces of organic matter uniform soil mixture within about $3-4 \mathrm{~cm}$ of the top of the pot. Only healthy and uniform seedlings were transplanted in the evening. Seedlings were transplanted 3-4 $\mathrm{cm}$ deep in pots. Three seedlings per pot were transplanted. Light irrigation given after completion of transplanting. The experiment was conducted with three replication in randomized block design along with eleven treatments (Table 1) with five selected PGPR namely (PR3, PR5, PR6, PR24 and PR29Tomato plant verity NTL-186 was transplanted in pot in rabi season on second 
week of February 2016. The organic manure applied was FYM 10 t/ha were well incorporated in the experimental (pots) field 10 days before transplanting of seedling. According to the treatment the NPK fertilizer (NPK 120:60:50kg/ha) are applied before transplanting. The treatment combination of PGPR with FYM and NPK are presented in table 2 .

\section{Growth and Yield observations}

The percent germination was calculated by following formula. Controls seeds without bacterial cultures were used for comparison. The root and shoot elongation was measured at interval of 3 days up to 11 days

Seed germination $\%$

$=\underline{\text { No of germinated seed }} \times 100$

No of total seeds

Root length of seedling in Measuring scale on $3,5,7$ and 9 days and divide them by 5 . Shoot length of seedling measuring scale on 3, 5, 7 and 9 days and divide them by 5 . The height of three randomly selected plants from each pot was measured with the help of measuring tape from soil surface up to the leaf peak, $(\mathrm{cm})$ in natural condition at 60 days after transplanting. The average height of plant of each replication was recorded and subjected to statistical analysis. The branches of three randomly selected plants from each pot was measured at 60 days after transplanting. The average Number of branches per plant of each replication was recorded and subjected to statistical analysis. All the leaves from three selected plants from each replication of all the treatments were counted at 60 days after transplanting. The average number of leaves per plant of each replication was recorded and subjected to statistical analysis. All the flowers from three selected plants from each replication of all the treatments were counted at 40 days after transplanting. The average number of flowers per plant of each replication was recorded and subjected to statistical analysis. All the fruits from three selected plants from each replication of all the treatments were counted at 60 days after transplanting. The average total number of fruits per plant of each replication was recorded and subjected to statistical analysis. All the fresh fruits from three selected plants from each replication of all the treatments were weight after picking. The average fresh fruits weight per plant of each replication was recorded and subjected to statistical analysis. Fresh weight of the three selected plants were recorded in each pot and average fresh weight was calculated. This calculated value was assumed as average weight of the rest of remaining plant per-pot. We have took the same plant taken for fresh weight form every treatment for dry weight and dried in the drier for dehydration. It was dried for 5-6 hours at the temperature of $50-60^{\circ} \mathrm{C}$. The dry weights of all randomly selected plant in each pot were added together and average calculated.

\section{Statistical analysis}

In the present experiment, completely randomized design (CRD) was applied. The analysis of variance technique was applied for drawing conclusions from the data. The calculated value of $\mathrm{F}$ was compared with tabulated value at $5 \%$ level of probability for the appropriate degree of freedom (Fisher 1950).

\section{Results and Discussion}

\section{Growth parameters}

Figure 1 shows that various treatment combinations significantly influenced the germination (\%) in treatment $\mathrm{T}_{3}$ (PR6) germination $(\%)$ was highest $(100 \%)$ followed by (90\%) $\mathrm{T}_{5}$ (PR29). The lowest germination found in $\mathrm{T}_{0}$ (control) $(60 \%)$. Table 1 shows 
that various treatment combinations significantly influenced the Root length of seedling $(\mathrm{cm})$ in treatment $\mathrm{T}_{3}$ (PR6) Root length $(\mathrm{cm})$ was highest $(6.00 \mathrm{~cm})$ followed by $(5.80 \mathrm{~cm}) \mathrm{T}_{5}$ (PR29). The lowest root length of seedling $(\mathrm{cm})$ found in $\mathrm{T}_{0}$ (control) $(4.20 \mathrm{~cm})$

Table 2 shows that various treatment combinations significantly influenced the Shoot length of Seedling $(\mathrm{cm})$ in treatment $\mathrm{T}_{3}$ (PR6) Shoot length of Seedling $(\mathrm{cm})$ was highest $(6.43 \mathrm{~cm})$ followed by $(6.23 \mathrm{~cm}) \mathrm{T}_{5}$ (PR29). The lowest Shoot length of Seedling (cm) found in $\mathrm{T}_{0}$ (control) $(5.13 \mathrm{~cm})$. In pot culture, and field trials $P$. fluorescence (SS5) enhanced the growth of tomato plants. Significant increase in root and shoot weight, length, fruit yield per plant, and total fruit yield was recorded. The strain SS5 was significantly rhizospheric competent and stabilized in the rhizosphere, without disturbing thenormal indigenous bacterial population. Ahirwar, et al., (2015)

The results pertaining of the effect applied through different PGPRs (PR3, PR5, PR6, PR24 and PR29) on plant height of Tomato are graphically presented in Table 3 at 60 DAT. PR3- PGPRs (PR3) application significantly influenced the plant height $(\mathrm{cm})$ over control. Table 3 reveals that the maximum plant height $(\mathrm{cm})(65.82 \mathrm{~cm})$ was recorded with $\mathrm{T}_{7}$ (PR3+NPK 100\%+FYM $100 \%)$ followed by $(64.94 \mathrm{~cm})$ in $\mathrm{T}_{8}$ (PR3+NPK 100\%+FYM 75\%) i.e. which were significantly higher than other treatment. The lowest plant height $(\mathrm{cm})(48.82 \mathrm{~cm})$ was observed in treatment $\mathrm{T}_{0}$ (control). PR5PGPRs (PR5) application significantly influenced the plant height $(\mathrm{cm})$ over control. Table 3 reveals that the maximum plant height (cm) $(67.04 \mathrm{~cm})$ was recorded with $\mathrm{T}_{7}$ (PR5+NPK 100\%+FYM 100\%) followed by $(66.71 \mathrm{~cm})$ in $\mathrm{T}_{8} \quad(\mathrm{PR} 5+\mathrm{NPK} 100 \%+\mathrm{FYM}$ $75 \%)$ i.e. which were significantly higher than other treatment. The lowest plant height $(\mathrm{cm})$
$(48.82 \mathrm{~cm})$ was observed in treatment $\mathrm{T}_{0}$ (control). PR24-PGPRs (PR24) application significantly influenced the plant height $(\mathrm{cm})$ over control. Table 3 reveals that the maximum plant height $(\mathrm{cm})(66.39 \mathrm{~cm})$ was recorded with $\mathrm{T}_{7}$ (PR24+NPK 100\%+FYM $100 \%)$ followed by $(65.74 \mathrm{~cm})$ in $\mathrm{T}_{8}$ (PR24+NPK 100\%+FYM 75\%) i.e. which were significantly higher than other treatment. The lowest plant height $(\mathrm{cm})(48.82 \mathrm{~cm})$ was observed in treatment $\mathrm{T}_{0}$ (control). PR29PGPRs (PR29) application significantly influenced the plant height $(\mathrm{cm})$ over control. Table 3 reveals that the maximum plant height (cm) $(68.39 \mathrm{~cm})$ was recorded with $\mathrm{T}_{7}$ (PR29+NPK 100\%+FYM 100\%) followed by $(66.85 \mathrm{~cm})$ in $\mathrm{T}_{8}$ (PR29+ NPK 100\% FYM $75 \%)$ i.e. which were significantly higher than other treatment. The lowest plant height $(\mathrm{cm})$ $(48.82 \mathrm{~cm})$ was observed in treatment $\mathrm{T}_{0}$ (control).

The results pertaining of the effect applied through different PGPRs (PR3, PR5, PR6, PR24 and PR29) on number of branches of Tomato are graphically presented in Table 4. PGPRs (PR3) application significantly influenced the number of branches over control. Table 4 reveals that the maximum number of branches (11.33) was recorded with $\mathrm{T}_{7}$ (PR3+NPK 100\%+FYM 100\%) followed by (10.33) in $\mathrm{T}_{8}$ (PR3+NPK 100\%+FYM $75 \%)$ i.e. which were significantly higher than other treatment. The lowest number of branches (7.00) was observed in treatment $T_{0}$ (control). PGPRs (PR5) application significantly influenced the number of branches over control. Table 4 reveals that the maximum number of branches (12.00) was recorded with $\mathrm{T}_{7}$ (PR5+NPK 100\%+FYM $100 \%$ ) followed by (11.33) in $\mathrm{T}_{8}$ (PR5+NPK $100 \%+F Y M \quad 75 \%$ ) i.e. which were significantly higher than other treatment. The lowest number of branches (7.00) was observed in treatment $\mathrm{T}_{0}$ (control). PGPRs (PR6) application significantly influenced the 
number of branches over control. Table 4 reveals that the maximum number of branches (14.67) was recorded with $\mathrm{T}_{7}$ (PR6+NPK $100 \%+F Y M 100 \%)$ followed by (12.33) in $\mathrm{T}_{8}$ (PR6+NPK 100\%+FYM 75\%) i.e. which were significantly higher than other treatment. The lowest number of branches (7.00) was observed in treatment $\mathrm{T}_{0}$ (control). Results of the current study showed the positive impacts of $P$. fluorescence on growth of tomato plant (number of branches per plant) compared to control. So as a simple and safe method, the seeds of tomato plant before planting can be inoculated with $P$. fluorescence to improvement plant growth efficiency. It appears that can lead to improve quantity and quality of tomato (Lycopersicon esculentum) plant by accumulation of organic and inorganic components. Ahirwar et al.,(2015).

PGPRs (PR3) application significantly influenced the number of leaves/plants over control. Table 5 reveals that the maximum number of leaves/plants (47.33) was recorded with $\mathrm{T}_{7}$ (PR3+NPK 100\%+FYM 100\%) followed by (45.00) in $\mathrm{T}_{8}$ (PR3+NPK $100 \%+\mathrm{FYM} 75 \%$ ) i.e. which were significantly higher than other treatment. The lowest number of leaves/plants (36.00) was observed in treatment $\mathrm{T}_{0}$ (control). PGPRs (PR5) application significantly influenced the number of leaves/plants over control. Table 5 reveals that the maximum number of leaves/plants (48.67) was recorded with $\mathrm{T}_{7}$ (PR5+NPK 100\%+FYM 100\%) followed by (46.00) in $\mathrm{T}_{8}$ (PR5+NPK 100\%+FYM 75\%) i.e. which were significantly higher than other treatment. The lowest number of leaves/plants (36.00) was observed in treatment $\mathrm{T}_{0}$ (control). PGPRs (PR6) application significantly influenced the number of leaves/plants over control. Table 5 reveals that the maximum number of leaves/plants (50.33) was recorded with $\mathrm{T}_{7}$ (PR6+NPK 100\%+FYM 100\%) followed by (47.67) in $\mathrm{T}_{8}$ (PR6+NPK $100 \%+$ FYM $75 \%$ ) i.e. which were significantly higher than other treatment. The lowest number of leaves/plants (36.00) was observed in treatment $\mathrm{T}_{0}$ (control). PGPRs (PR24) application significantly influenced the number of leaves/plants over control. Table 5 reveals that the maximum number of leaves /plants (48.00) was recorded with $\mathrm{T}_{7}$ (PR24+NPK 100\%+FYM 100\%) followed by (45.33) in $\mathrm{T}_{8}$ (PR24+NPK 100\%+FYM 75\%) i.e. which were significantly higher than other treatment. The lowest number of leaves /plants (36.00) was observed in treatment $\mathrm{T}_{0}$ (control). Bacterial inoculations (Azospirillum) improved the Tomato growth and growth parameters. The performance of the plants was better in inoculated treatments in comparison to the control(Kannahi and Ramya., 2015).

\section{Yield and yield attributes}

PGPRs (PR3) application significantly influenced the number of flowers/plants over control. Table 6 reveals that the maximum number of flowers/plants (17.00) was recorded with $\mathrm{T}_{7}$ (PR3+NPK 100\%+FYM 100\%) followed by (15.33) in $\mathrm{T}_{8}$ (PR3+NPK $100 \%+\mathrm{FYM} 75 \%$ ) i.e. which were significantly higher than other treatment. The lowest number of flowers/plants (9.33) was observed in treatment $\mathrm{T}_{0}$ (control). PGPRs (PR5) application significantly influenced the number of flowers/plants over control. Table 4.7 and fig 4.7 reveals that the maximum number of flowers/plants (18.00) was recorded with $\mathrm{T}_{7}$ (PR5+NPK 100\%+FYM 100\%) followed by (17.00) in $\mathrm{T}_{8}$ (PR5+NPK $100 \%+$ FYM $75 \%)$ i.e. which were significantly higher than other treatment. The lowest number of flowers/plants (9.33) was observed in treatment $\mathrm{T}_{0}$ (control). PGPRs (PR6) application significantly influenced the number of flowers/plants over control. Table 6 reveals that the maximum number of flowers/plants (20.33) was recorded with $\mathrm{T}_{7}$ (PR6+NPK 100\%+FYM 100\%) followed by (18.33) in $\mathrm{T}_{8}(\mathrm{PR} 6+\mathrm{NPK} 100 \%+\mathrm{FYM} 75 \%)$ 
i.e. which were significantly higher than other treatment. The lowest number of flowers/plants (9.33) was observed in treatment $\mathrm{T}_{0}$ (control). PGPRs (PR24) application significantly influenced the number of flowers/plants over control. Table 6 reveals that the maximum number of flowers/plants (17.67) was recorded with $\mathrm{T}_{7}$ (PR24+NPK 100\%+FYM 100\%) followed by (15.67) in $\mathrm{T}_{8}$ (PR24+NPK 100\%+FYM 75\%) i.e. which were significantly higher than other treatment. The lowest number of flowers/plants (9.33) was observed in treatment $\mathrm{T}_{0}$ (control). PGPRs (PR29) application significantly influenced the number of flowers/plants over control. Table 6 reveals that the maximum number of flowers/plants (18.67) was recorded with $\mathrm{T}_{7}$ (PR23+NPK 100\%+FYM 100\%) followed by (17.33) in $\mathrm{T}_{8}$ (PR23+ NPK 100\% FYM 75\%) i.e. which were significantly higher than other treatment. The lowest number of flowers/plants (9.33) was observed in treatment $\mathrm{T}_{0}$ (control).

PGPRs (PR3) application significantly influenced the number of fruit/plant over control. Table 7 reveals that the maximum number of fruit/plant (13.67) was recorded with $\mathrm{T}_{7} \quad$ (PR3+NPK $\left.100 \%+\mathrm{FYM} \quad 100 \%\right)$ followed by (12.67) in $\mathrm{T}_{8}$ (PR3+NPK $100 \%+\mathrm{FYM} \quad 75 \%)$ i.e. which were significantly higher than other treatment. The lowest number of fruit/plant (7.00) was observed in treatment $\mathrm{T}_{0}$ (control). PGPRs (PR5) application significantly influenced the number of fruit/plant over control. Table 4.8 and fig 4.8 reveals that the maximum number of fruit/plant (14.67) was recorded with $\mathrm{T}_{7}$ (PR5+NPK 100\%+FYM 100\%) followed by (13.67) in $\mathrm{T}_{8}$ (PR5+NPK 100\%+FYM 75\%) i.e. which were significantly higher than other treatment. The lowest number of fruit/plant (7.00) was observed in treatment $\mathrm{T}_{0}$ (control). PGPRs (PR6) application significantly influenced the number of fruit/plant over control. Table 4.8 and fig 4.8 reveals that the maximum number of fruit/plant (17.00) was recorded with $\mathrm{T}_{7}$ (PR6+NPK 100\%+FYM $100 \%$ ) followed by (14.67) in $\mathrm{T}_{8}$ (PR6+NPK $100 \%+\mathrm{FYM} 75 \%$ i.e. which were significantly higher than other treatment. The lowest number of fruit/plant (7.00) was observed in treatment $T_{0}$ (control). PGPRs (PR24) application significantly influenced the number of fruit/plant over control. Table 4.8 and fig 4.8 reveals that the maximum number of fruit/plant (14.00) was recorded with $\mathrm{T}_{7}$ (PR24+NPK 100\%+FYM 100\%) followed by (13.33) in $\mathrm{T}_{8}$ (PR24+NPK 100\%+FYM 75\%) i.e. which were significantly higher than other treatment. The lowest number of fruit/plant (7.00) was observed in treatment $\mathrm{T}_{0}$ (control). PGPRs (PR29) application significantly influenced the number of fruit/plant over control. Table 4.8 and fig 4.8 reveals that the maximum number of fruit/plant (15.00) was recorded with $\mathrm{T}_{7}$ (PR29+NPK 100\%+FYM $100 \%)$ followed by (14.00) in $\mathrm{T}_{8}(\mathrm{PR} 23+\mathrm{NPK}$ $100 \%$ FYM 75\%) i.e. which were significantly higher than other treatment. The lowest number of fruit/plant (7.00) was observed in treatment $\mathrm{T}_{0}$ (control). In pot culture and field trials $P$. fluorescence (SS5) enhanced the growth of tomato plants. Significant increase in root and shoot weight, length, fruit yield per plant, and total fruit yield was recorded. The strain SS5 was significantly rhizopheric competent and stabilized in the rhizosphere, without disturbing the normal indigenous bacterial population. Ahirwar, et al., (2015). PGPRs (PR3) application significantly influenced the fresh fruit weight (g/plant) over control. Table 8 reveals that the maximum fruit weight (g/plant) $(647.00 \mathrm{~g})$ was recorded with $\mathrm{T}_{7}$ (PR3+NPK 100\%+FYM 100\%) followed by $(556.67 \mathrm{~g})$ in $\mathrm{T}_{8}$ (PR3+NPK $100 \%+$ FYM $75 \%$ ) i.e. which were significantly higher than other treatment. The lowest fruit weight (gm) (353.33) was observed in treatment $\mathrm{T}_{0}$ (control). PGPRs (PR5) application significantly influenced the fresh fruit weight (g/plant) over control. 
Table.1 Treatment details

\begin{tabular}{|l|l|l|l|}
\hline S.No & Treatments & Recommended Dose & Applied to Soil (t/ha) \\
\hline $\mathbf{1}$ & PGPR & ------- & $\begin{array}{l}\text { Seed treatment }-1.0 \% \text { volume } \\
\text { for 5-10min }\end{array}$ \\
\hline $\mathbf{2}$ & FYM & $10 \mathrm{t} / \mathrm{ha}$ & $\begin{array}{l}\text { Seed treatment }-1.0 \% \text { volume } \\
\text { for 5-10 min }+50 \% \text { of } \\
\text { recommended doses all organic } \\
\text { sources and inorganic fertilizer }\end{array}$ \\
\hline $\mathbf{3}$ & NPK & $120: 60: 50 \mathrm{~kg} / \mathrm{ha}$ & \\
\hline
\end{tabular}

Table.2 Treatment combination of PGPR with FYM and NPK

\begin{tabular}{|c|c|c|c|c|c|c|}
\hline \multirow[t]{2}{*}{ S.No } & \multirow[t]{2}{*}{ Tr. } & \multicolumn{5}{|c|}{ Treatments } \\
\hline & & PR3 & PR5 & PR6 & PR24 & PR29 \\
\hline 1 & T0 & Control & Control & CONTROL & CONTROL & CONTROL \\
\hline 2 & $\mathrm{~T} 1$ & PGPR & PGPR & PGPR & PGPR & PGPR \\
\hline 3 & $\mathrm{~T} 2$ & PGPR+NPK & PGPR+NPK & PGPR+NPK & PGPR+NPK & PGPR+NPK \\
\hline 4 & T3 & $\begin{array}{l}\text { PGPR+FYM } \\
(100 \%)\end{array}$ & $\begin{array}{l}\text { PGPR+FYM } \\
(100 \%)\end{array}$ & $\begin{array}{l}\text { PGPR+FYM } \\
(100 \%)\end{array}$ & $\begin{array}{l}\text { PGPR+FYM } \\
(100 \%)\end{array}$ & $\begin{array}{l}\text { PGPR+FYM } \\
(100 \%)\end{array}$ \\
\hline 5 & $\mathrm{~T} 4$ & $\begin{array}{l}\text { PGPR+FYM } \\
(75 \%)\end{array}$ & $\begin{array}{l}\text { PGPR+FYM } \\
(75 \%)\end{array}$ & $\begin{array}{l}\text { PGPR+FYM } \\
(75 \%)\end{array}$ & $\begin{array}{l}\text { PGPR+FYM } \\
(75 \%)\end{array}$ & $\begin{array}{l}\text { PGPR+FYM } \\
(75 \%)\end{array}$ \\
\hline 6 & T5 & $\begin{array}{l}\text { PGPR+FYM } \\
(50 \%)\end{array}$ & $\begin{array}{l}\text { PGPR+FYM } \\
(50 \%)\end{array}$ & $\begin{array}{l}\text { PGPR+FYM } \\
(50 \%)\end{array}$ & $\begin{array}{l}\text { PGPR+FYM } \\
(50 \%)\end{array}$ & $\begin{array}{l}\text { PGPR+FYM } \\
(50 \%)\end{array}$ \\
\hline 7 & T6 & $\begin{array}{l}\text { PGRR+FYM } \\
(25 \%)\end{array}$ & $\begin{array}{l}\text { PGRR+FYM } \\
(25 \%)\end{array}$ & $\begin{array}{l}\text { PGRR+FYM } \\
(25 \%)\end{array}$ & $\begin{array}{l}\text { PGRR+FYM } \\
(25 \%)\end{array}$ & $\begin{array}{l}\text { PGRR+FYM } \\
(25 \%)\end{array}$ \\
\hline 8 & $\mathrm{~T} 7$ & $\begin{array}{l}\text { PGPR+NPK } \\
(100 \%)+F Y M \\
(100 \%)\end{array}$ & $\begin{array}{l}\text { PGPR+NPK } \\
(100 \%)+F Y M \\
(100 \%)\end{array}$ & $\begin{array}{l}\text { PGPR+NPK } \\
(100 \%)+F Y M \\
(100 \%)\end{array}$ & $\begin{array}{l}\text { PGPR+NPK } \\
(100 \%)+F Y M \\
(100 \%)\end{array}$ & $\begin{array}{l}\text { PGPR+NPK } \\
(100 \%)+F Y M \\
(100 \%)\end{array}$ \\
\hline 9 & $\mathrm{~T} 8$ & $\begin{array}{l}\text { PGPR+NPK } \\
(100 \%)+F Y M \\
(75 \%)\end{array}$ & $\begin{array}{l}\text { PGPR+NPK } \\
(100 \%)+F Y M \\
(75 \%)\end{array}$ & $\begin{array}{l}\text { PGPR+NPK } \\
(100 \%)+F Y M \\
(75 \%)\end{array}$ & $\begin{array}{l}\text { PGPR+NPK } \\
(100 \%)+F Y M \\
(75 \%)\end{array}$ & $\begin{array}{l}\text { PGPR+NPK } \\
(100 \%)+F Y M \\
(75 \%)\end{array}$ \\
\hline 10 & T9 & $\begin{array}{l}\text { PGPR+NPK } \\
(100 \%)+\mathrm{FYM} \\
(50 \%)\end{array}$ & $\begin{array}{l}\text { PGPR+NPK } \\
(100 \%)+F Y M \\
(50 \%)\end{array}$ & $\begin{array}{l}\text { PGPR+NPK } \\
(100 \%)+\mathrm{FYM} \\
(50 \%)\end{array}$ & $\begin{array}{l}\text { PGPR+NPK } \\
(100 \%)+F Y M \\
(50 \%)\end{array}$ & $\begin{array}{l}\text { PGPR+NPK } \\
(100 \%)+F Y M \\
(50 \%)\end{array}$ \\
\hline 11 & $\mathrm{~T} 10$ & $\begin{array}{l}\text { PGPR+NPK } \\
(100 \%)+F Y M \\
(25 \%)\end{array}$ & $\begin{array}{l}\text { PGPR+NPK } \\
(100 \%)+F Y M \\
(25 \%)\end{array}$ & $\begin{array}{l}\text { PGPR+NPK } \\
(100 \%)+F Y M \\
(25 \%)\end{array}$ & $\begin{array}{l}\text { PGPR+NPK } \\
(100 \%)+F Y M \\
(25 \%)\end{array}$ & $\begin{array}{l}\text { PGPR+NPK } \\
(100 \%)+F Y M \\
(25 \%)\end{array}$ \\
\hline
\end{tabular}


Table.3 Effect of PGPRs (PR3, PR5, PR6, PR24 and PR29) on Root length of seedling of Tomato cv.NTL-186

\begin{tabular}{|l|c|c|}
\hline Tr. No. & Treatments & Root length of seedling $(\mathbf{c m})$ \\
\hline T0 & Control & 4.20 \\
\hline T1 & PR3 & 4.73 \\
\hline T2 & PR5 & 5.33 \\
\hline T3 & PR6 & 6.00 \\
\hline T4 & PR24 & 4.97 \\
\hline T5 & PR29 & 5.80 \\
\hline & CD $(\mathbf{0 . 0 5} \%)$ & 0.24 \\
\hline
\end{tabular}

Table.4 Effect of PGPRs (PR3, PR5, PR6, PR24 and PR29) on Shoot length of Seedling of Tomato cv.NTL-186

\begin{tabular}{|l|c|c|}
\hline Tr. No. & Treatment & Shoot length of seedling (cm) \\
\hline T0 & Control & 5.13 \\
\hline T1 & PR3 & 5.43 \\
\hline T2 & PR5 & 5.80 \\
\hline T3 & PR6 & 6.43 \\
\hline T4 & PR24 & 5.63 \\
\hline T5 & PR29 & 6.23 \\
\hline & CD $(\mathbf{0 . 0 5} \%)$ & 0.35 \\
\hline
\end{tabular}

Table. 5 Effect of PGPRs (PR3, PR5, PR6, PR24 and PR29) on Plant height at 60 DAT of Tomato cv.NTL-186

\begin{tabular}{|l|l|c|c|c|c|c|}
\hline \multirow{2}{*}{ Tr. } & Treatments & \multicolumn{5}{|c|}{ Plant height $(\mathbf{c m})$} \\
\cline { 3 - 7 } & & PR3 & PR5 & PR6 & PR24 & PR29 \\
\hline T0 & control & 48.82 & 48.82 & 48.82 & 48.82 & 48.82 \\
\hline T1 & PGPR & 54.57 & 56.33 & 60.80 & 55.47 & 57.50 \\
\hline T2 & PGPR+NPK (100\%) & 56.67 & 58.23 & 63.20 & 57.83 & 62.37 \\
\hline T3 & PGPR+FYM (100\%) & 60.10 & 63.17 & 65.00 & 62.45 & 63.41 \\
\hline T4 & PGPR+FYM (75\%) & 59.13 & 62.67 & 64.37 & 61.70 & 62.91 \\
\hline T5 & PGPR+FYM (50\%) & 58.43 & 60.50 & 62.17 & 59.80 & 61.38 \\
\hline T6 & PGPR+FYM (25\%) & 57.67 & 59.73 & 61.70 & 59.03 & 60.45 \\
\hline T7 & PGPR+NPK+FYM (100\%) & 65.82 & 67.04 & 70.10 & 66.39 & 68.39 \\
\hline T8 & PGPR+NPK+FYM (75\%) & 64.94 & 66.71 & 68.29 & 65.74 & 66.85 \\
\hline T9 & PGPR+NPK+FYM (50\%) & 63.32 & 65.34 & 67.07 & 64.63 & 65.24 \\
\hline T10 & PGPR+NPK+FYM (25\%) & 62.67 & 64.53 & 66.27 & 63.60 & 64.70 \\
\hline CD $(\mathbf{0 . 0 5} \%)$ & & 2.75 & 1.83 & 2.01 & 1.75 & 2.33 \\
\hline
\end{tabular}


Table.6 Effect of PGPRs (PR3, PR5, PR6, PR24 and PR29) on number of branches at 60 DAT of Tomato cv.NTL-186

\begin{tabular}{|l|l|c|c|c|c|c|}
\hline \multirow{2}{*}{ Tr. } & \multirow{2}{*}{ Treatments } & \multicolumn{5}{|c|}{ Number of branches per plant } \\
\cline { 3 - 6 } & & PR3 & PR5 & PR6 & PR24 & PR29 \\
\hline T0 & CONTROL & 7.00 & 7.00 & 7.00 & 7.00 & 7.00 \\
\hline T1 & PGPR & 8.00 & 8.67 & 9.67 & 8.33 & 9.00 \\
\hline T2 & PGPR+NPK (100\%) & 8.33 & 9.00 & 10.00 & 8.67 & 9.33 \\
\hline T3 & PGPR+FYM (100\%) & 9.00 & 9.67 & 10.67 & 9.33 & 10.00 \\
\hline T4 & PGPR+FYM (75\%) & 8.67 & 9.33 & 9.67 & 9.00 & 9.33 \\
\hline T5 & PGPR+FYM (50\%) & 8.00 & 8.33 & 9.33 & 8.33 & 8.67 \\
\hline T6 & PGPR+FYM (25\%) & 7.67 & 8.00 & 9.00 & 8.00 & 8.33 \\
\hline T7 & PGPR+NPK+FYM(100\%) & 11.33 & 12.00 & 14.67 & 11.67 & 12.67 \\
\hline T8 & PGPR+NPK+FYM(75\%) & 10.33 & 11.33 & 12.33 & 10.67 & 11.67 \\
\hline T9 & PGPR+NPK+FYM(50\%) & 10.00 & 10.67 & 12.00 & 10.33 & 11.33 \\
\hline T10 & PGPR+NPK+FYM(25\%) & 9.67 & 10.33 & 11.33 & 10.00 & 11.00 \\
\hline CD $(\mathbf{0 . 0 5}$ & \%) & 1.28 & 0.78 & 1.10 & 0.98 & 0.98 \\
\hline
\end{tabular}

Table.7 Effect of PGPRs (PR3, PR5, PR6, PR24 and PR29) on Number of leaves /plants at 60 DAT of Tomato (Solanum lycopersicum L.Mill.) cv.NTL-186

\begin{tabular}{|l|l|c|c|c|c|c|}
\hline \multirow{2}{*}{ Tr. } & Treatments & \multicolumn{5}{|c|}{ Number of leaves per plants } \\
\cline { 3 - 6 } & & PR3 & PR5 & PR6 & PR24 & PR29 \\
\hline T0 & CONTROL & 36 & 36 & 36 & 36 & 36 \\
\hline T1 & PGPR & 38 & 38.67 & 39.67 & 38.33 & 39 \\
\hline T2 & PGPR+NPK (100\%) & 38.33 & 39 & 40 & 38.67 & 39.67 \\
\hline T3 & PGPR+FYM (100\%) & 40 & 41 & 43.33 & 40.67 & 42.67 \\
\hline T4 & PGPR+FYM (75\%) & 39.67 & 40.67 & 42.33 & 40 & 42 \\
\hline T5 & PGPR+FYM (50\%) & 39.33 & 40 & 41.67 & 39.67 & 40.33 \\
\hline T6 & PGPR+FYM (25\%) & 38 & 38.67 & 39.67 & 38.33 & 39 \\
\hline T7 & PGPR+NPK+FYM(100\%) & 47.33 & 48.67 & 50.33 & 48 & 49.33 \\
\hline T8 & PGPR+NPK+FYM(75\%) & 45 & 46 & 47.67 & 45.33 & 47 \\
\hline T9 & PGPR+NPK+FYM(50\%) & 44 & 45 & 46.33 & 44.67 & 45.33. \\
\hline T10 & PGPR+NPK+FYM(25\%) & 41.33 & 43.67 & 45 & 42 & 44.33 \\
\hline CD $(\mathbf{0 . 0 5}$ & \%) & 1.80 & 1.18 & 2.60 & 1.21 & 1.64 \\
\hline
\end{tabular}


Table.8 Effect of PGPRs (PR3, PR5, PR6, PR24 and PR29) on Number of flowers/plants at 60 DAT of Tomato cv.NTL-186

\begin{tabular}{|l|l|c|c|c|c|c|}
\hline \multirow{2}{*}{ Tr. } & \multirow{2}{*}{ Treatments } & \multicolumn{5}{|c|}{ Number of flowers per plants } \\
\cline { 3 - 6 } & & PR3 & PR5 & PR6 & PR24 & PR29 \\
\hline T0 & control & 9.33 & 9.33 & 9.33 & 9.33 & 9.33 \\
\hline T1 & PGPR & 11.00 & 12.00 & 12.67 & 11.67 & 12.33 \\
\hline T2 & PGPR+NPK (100\%) & 11.67 & 12.67 & 14.00 & 12.00 & 13.00 \\
\hline T3 & PGPR+FYM (100\%) & 12.33 & 13.67 & 15.00 & 13.00 & 14.33 \\
\hline T4 & PGPR+FYM (75\%) & 12.00 & 13.33 & 14.33 & 12.67 & 13.67 \\
\hline T5 & PGPR+FYM (50\%) & 11.67 & 13.00 & 14.00 & 12.00 & 13.33 \\
\hline T6 & PGPR+FYM (25\%) & 11.33 & 12.67 & 13.67 & 11.33 & 13.00 \\
\hline T7 & PGPR+NPK+FYM(100\%) & 17.00 & 18.00 & 20.33 & 17.67 & 18.67 \\
\hline T8 & PGPR+NPK+FYM(75\%) & 15.33 & 17.00 & 18.33 & 15.67 & 17.33 \\
\hline T9 & PGPR+NPK+FYM(50\%) & 14.33 & 16.00 & 17.67 & 15.00 & 16.33 \\
\hline T10 & PGPR+NPK+FYM(25\%) & 13.67 & 15.00 & 16.33 & 14.33 & 15.33 \\
\hline CD $(\mathbf{0 . 0 5}$ & \%) & 0.83 & 0.66 & 0.97 & 0.83 & 1.44 \\
\hline
\end{tabular}

Table.9 Effect of PGPRs (PR3, PR5, PR6, PR24 and PR29) on number of fruit/plant of Tomato cv.NTL-186

\begin{tabular}{|l|l|c|c|c|c|c|}
\hline \multirow{2}{*}{ Tr. } & \multirow{2}{*}{ Treatments } & \multicolumn{4}{|c|}{ Number of fruit per plant } \\
\cline { 3 - 6 } & & PR3 & PR5 & PR6 & PR24 & PR29 \\
\hline T0 & control & 7.00 & 7.00 & 7.00 & 7.00 & 7.00 \\
\hline T1 & PGPR & 8.00 & 9.00 & 9.67 & 8.67 & 9.33 \\
\hline T2 & PGPR+NPK (100\%) & 8.67 & 9.33 & 10.00 & 9.00 & 9.67 \\
\hline T3 & PGPR+FYM (100\%) & 10.33 & 11.33 & 12.33 & 11.00 & 11.67 \\
\hline T4 & PGPR+FYM (75\%) & 10.00 & 11.00 & 12.00 & 10.33 & 11.33 \\
\hline T5 & PGPR+FYM (50\%) & 9.67 & 10.67 & 11.67 & 10.33 & 11.33 \\
\hline T6 & PGPR+FYM (25\%) & 9.33 & 10.00 & 11.00 & 9.67 & 10.67 \\
\hline T7 & PGPR+NPK+FYM(100\%) & 13.67 & 14.67 & 17.00 & 14.00 & 15.00 \\
\hline T8 & PGPR+NPK+FYM(75\%) & 12.67 & 13.67 & 14.67 & 13.33 & 14.00 \\
\hline T9 & PGPR+NPK+FYM(50\%) & 12.00 & 12.67 & 13.33 & 12.33 & 13.00 \\
\hline T10 & PGPR+NPK+FYM(25\%) & 11.00 & 12.00 & 12.67 & 11.67 & 12.33 \\
\hline CD $(\mathbf{0 . 0 5}$ \%) & 1.22 & 1.18 & 1.44 & 1.72 & 1.35 \\
\hline
\end{tabular}


Table.10 Effect of PGPRs (PR3, PR5, PR6, PR24 and PR29) on Fresh fruit weight of Tomato (Solanum lycopersicum L.Mill.) cv.NTL-186

\begin{tabular}{|l|l|c|c|c|c|c|}
\hline \multirow{2}{*}{ Tr. } & \multirow{2}{*}{ Treatments } & \multicolumn{5}{|c|}{ Fresh Fruit weight (g/plant) } \\
\cline { 3 - 6 } & & PR3 & PR5 & PR6 & PR24 & PR29 \\
\hline T0 & CONTROL & 353.33 & 353.33 & 353.33 & 353.33 & 353.33 \\
\hline T1 & PGPR & 363.67 & 366.67 & 376.67 & 364.33 & 370.00 \\
\hline T2 & PGPR+NPK (100\%) & 393.33 & 408.67 & 441.67 & 407.33 & 420.00 \\
\hline T3 & PGPR+FYM (100\%) & 411.67 & 421.00 & 462.67 & 417.00 & 443.00 \\
\hline T4 & PGPR+FYM (75\%) & 371.67 & 386.67 & 421.00 & 375.33 & 407.67 \\
\hline T5 & PGPR+FYM (50\%) & 377.00 & 381.67 & 405.00 & 378.67 & 391.67 \\
\hline T6 & PGPR+FYM (25\%) & 358.33 & 371.00 & 399.00 & 362.67 & 379.33 \\
\hline T7 & PGPR+NPK+FYM(100\%) & 647.00 & 682.33 & 718.33 & 661.00 & 690.00 \\
\hline T8 & PGPR+NPK+FYM(75\%) & 556.67 & 597.33 & 619.67 & 577.33 & 602.67 \\
\hline T9 & PGPR+NPK+FYM(50\%) & 510.00 & 534.67 & 555.67 & 520.67 & 548.33 \\
\hline T10 & PGPR+NPK+FYM(25\%) & 445.33 & 471.67 & 513.67 & 461.33 & 502.00 \\
\hline CD $(\mathbf{0 . 0 5}$ \%) & 52.74 & 72.20 & 31.00 & 67.71 & 61.14 \\
\hline
\end{tabular}

Table.11 Effect of PGPRs (PR3, PR5, PR6, PR24 and PR29) on fresh weight of plant of Tomato (Solanum lycopersicum L.Mill.) cv.NTL-186

\begin{tabular}{|l|l|c|c|c|c|c|}
\hline \multirow{2}{*}{ Tr. } & \multirow{2}{*}{ Treatments } & \multicolumn{5}{|c|}{ Fresh weight of plant (g/plant) } \\
\cline { 4 - 7 } T0 & Control & PR3 & PR5 & PR6 & PR24 & PR29 \\
\hline T1 & PGPR & 24.33 & 24.33 & 24.33 & 24.33 & 24.33 \\
\hline T2 & PGPR+NPK (100\%) & 27.55 & 28.33 & 28.77 & 27.97 & 28.67 \\
\hline T3 & PGPR+FYM (100\%) & 29.20 & 29.80 & 30.63 & 29.33 & 30.17 \\
\hline T4 & PGPR+FYM (75\%) & 29.87 & 30.99 & 31.91 & 30.33 & 31.33 \\
\hline T5 & PGPR+FYM (50\%) & 29.52 & 30.08 & 30.99 & 29.91 & 30.46 \\
\hline T6 & PGPR+FYM (25\%) & 29.18 & 29.92 & 30.44 & 29.64 & 30.25 \\
\hline T7 & PGPR+NPK+FYM(100\%) & 39.08 & 40.10 & 42.28 & 39.50 & 40.82 \\
\hline T8 & PGPR+NPK+FYM(75\%) & 35.29 & 36.99 & 38.42 & 35.67 & 37.73 \\
\hline T9 & PGPR+NPK+FYM(50\%) & 33.72 & 35.00 & 36.19 & 34.12 & 35.67 \\
\hline T10 & PGPR+NPK+FYM (25\%) & 32.01 & 33.91 & 34.45 & 33.03 & 34.00 \\
\hline CD $(\mathbf{0 . 0 5}$ \%) & 2.33 & 2.27 & 3.74 & 2.70 & 3.84 \\
\hline
\end{tabular}


Fig.4.1Effect of PGPRs (PR3, PR5, PR6, PR24 and PR29) on Germination of Tomato cv.NTL186

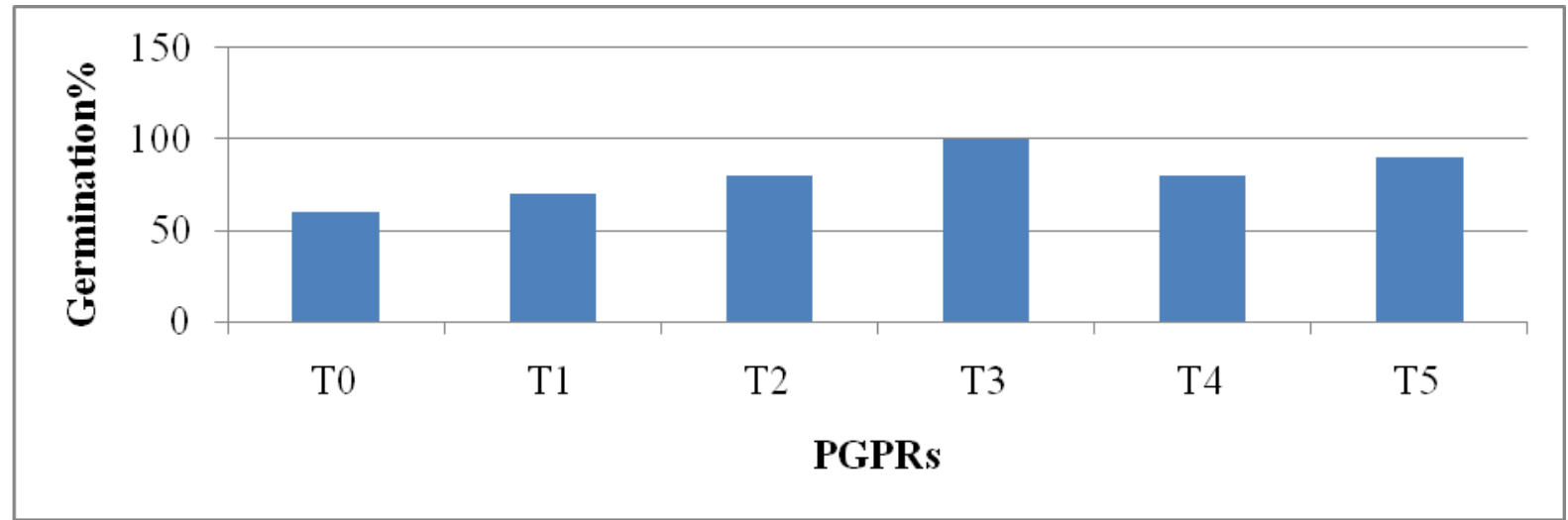

Table 4.9 and fig 4.9 reveals that the maximum fruit weight (g/plant) $(682.33 \mathrm{~g})$ was recorded with $\mathrm{T}_{7}$ (PR5+NPK 100\%+FYM $100 \%)$ followed by $(597.33 \mathrm{~g})$ in $\mathrm{T}_{8}$ (PR5+NPK 100\%+FYM 75\%) i.e. which were significantly higher than other treatment. The lowest fresh fruit weight (g/plant) $(353.33 \mathrm{~g})$ was observed in treatment $\mathrm{T}_{0}$ (control). Similar type of results also observed for other PGPR. In pot culture and field trials $P$. fluorescence (SS5) enhanced the growth of tomato plants. Significant increase in root and shoot weight, length, fruit yield per plant, and total fruit yield was recorded. The strain SS5 was significantly rhizopheric competent and stabilized in the rhizosphere, without disturbing thenormal indigenous bacterial population. Ahirwar et al., (2015).

PGPRs (PR3) application significantly influenced the fresh weight of plant (g/plant) over control. Table 9 reveals that the maximum fresh weight of plant (g/plant) (39.08) was recorded with $\mathrm{T}_{7}$ (PR3+NPK $100 \%+F Y M 100 \%$ ) followed by 35.29$)$ in $\mathrm{T}_{8}$ (PR3+NPK 100\%+FYM 75\%) i.e. which were significantly higher than other treatment. The lowest fresh weight of plant (g/plant) (24.33) was observed in treatment $\mathrm{T}_{0}$ (control). Similar type of results also made for other PGPR. Tomato plant tended to increased significantly the growth parameters (plant height, leaf number and area, fresh and dry weight) in the inoculated of Pseudomonas fluorescence SS5 compared to control tomato plant. Ahirwar, et al.,(2015).

PGPB promote plant growth by directly affect the metabolism of the plants by providing substances that are usually in short supply. PGPB are free-living soil, rhizosphere, rhizoplane, and phylosphere bacteria that, under some conditions, are beneficial for plants Most of the activities of PGPB have been studied in the rhizosphere. From the present investigation it is concluded that $\mathrm{T}_{7}$ $($ PR6+NPK $(100 \%)+$ FYM $100 \%)$ significantly increased the growth and yield of Tomato (Lycopersicon esculentum Mill.).

\section{References}

Ahirwar, N. K., Gupta, G., Singh, V., Rawlley, R. K. and Ramana, S. (2015) Influence on growth and fruit yield of tomato (Lycopersicon esculentum Mill.) plants by inoculation with Pseudomonas fluorescence (SS5): Possible role of plant growth promotion. Int. J.Curr. Microbiol.App. Sci, 4(2): 720-730.

Chatterjee R. and Thirumdasu R. K. (2014). Nutrient management in organic 
vegetable production. International Journal of Food, Agriculture and Veterinary Sciences, 4 (3): 156-170

Fisher, R.A. (1950) Statistical method for research workers. Oliver and Boyd Edinburg. London.

Hillel, D. (2005) Plant growth-promoting bacteria in agriculture and the environment, encyclopedia of soils in the environment,2005, (Editor-inChief) D. Hillel, Elsevier, Oxford, U.K. Vol. 1., pp. 103-115. 2200 p.

Jenny, S. and Malliga, P. (2016). Assessment of different concentrations of organic Manure on the growth and yield of Solanum lycopersicum L.(Tomato). IJIRSET DOI:10.15680/IJIRSET. 3722 -3731 .

Kannahi, M. and Ramya, R.(2015).Effect of biofertilizer, vermicompost, biocompost and chemical fertilizer on different morphological and phytochemical parameters of Lycopersicum esculentum L. World Journal of Pharmacy and Pharmaceutical Sciences, 4 (09): 1460-1469.
Kloepper, J.W. and Schroth, M.N. (1981) Relationship of in vitro antibiosis of plant growth promoting rhizobacteria to plant growth and the displacement of root microflora. Phytopathology 71: 1020-1024.

Maurya, U., Lal, E.P., Yadav, O.P., Prakash, A. and Singh, A. K. (2015). Plant growth promoting rhizobacteria and their activity against early blight of tomato. Indian J.L.Sci. 5 (1) : 57-62.

Naika, S., Lidt de Jeude, J.V., Goffau,M.De., Hilmi, M. and Dam, B.V. (2005). Cultivation of tomato : production, processing and marketing. Agromisa Foundation and CTA, Wageningen, 17: $1-92$

Peralta I. E. and Spooner D.M. (2007). History, origin and early cultivation of tomato (Solanaceae), Genetic improvements of solanaceous crops : tomato, Science publisher (2) 1-24

Ramakrishnan, K. and Selvakumar, G. (2012) Effect of biofertilizers on enhancement of growth and yield on Tomato (Lycopersicum esculentum Mill.), International Journal of Research in Botany ; 2(4): 20-23

\section{How to cite this article:}

Gagendra Singh Rajput and Ramteke, P.W. 2019. Impact of Plant Growth Promoting Rhizobacteria with FYM on the Growth, Yield Attribute and Yield of Tomato (Lycopersicon esculentum Mill.). Int.J.Curr.Microbiol.App.Sci. 8(09): 2219-2232.

doi: https://doi.org/10.20546/ijcmas.2019.809.256 